Rev. Int. Contam. Ambie. 33 (3) 393-401, 2017

DOI: 10.20937/RICA.2017.33.03.03

\title{
COMPARISON OF ORGANOCHLORINE PESTICIDE LEVELS BETWEEN HUMAN BLOOD SERUM AND ADIPOSE TISSUE
}

\author{
María Del Carmen MARTÍNEZ-VALENZUELA ${ }^{1 *}$, Stefan M. WALISZEWSKI ${ }^{2}$, \\ Sandra GÓMEZ-ARROYO ${ }^{3}$, Rafael VILLALOBOS-PIETRINI ${ }^{3}$, Carlos CALDERÓN-VÁZQUEZ ${ }^{4}$, \\ Daniel ORTEGA-MARTÍNEZ ${ }^{5}$, Enrique MEZA $^{2}$ and Mario CABA ${ }^{2}$
}

${ }^{1}$ Instituto de Investigación en Ambiente y Salud, Universidad de Occidente. Bulevar Macario Gaxiola y Carretera Internacional, Los Mochis, Sinaloa, México, C. P. 81223

${ }^{2}$ Centro de Investigaciones Biomédicas Universidad Veracruzana. Luis Castelazo, Colonia Industrial Ánima, Xalapa, Veracruz, México, C. P. 91190

${ }^{3}$ Centro de Ciencias de la Atmósfera, Universidad Nacional Autónoma de México. Ciudad Universitaria, Coyoacán, Ciudad de México, México, C. P. 04510

${ }^{4}$ Centro Interdisciplinario de Investigación para el Desarrollo Integral Regional, Unidad Sinaloa, Instituto Politécnico Nacional. Bulevar Juan de Dios Bátiz Paredes 250, Colonia San Joachin, Guasave, Sinaloa, México, C. P. 81101

${ }^{5}$ Universidad Popular Autónoma del Estado de Puebla. Departamento de Ciencias Biológicas, 13 Poniente 1927, Colonia Barrio de Santiago, Puebla, México, C. P. 72410

*Corresponding author: maria.martinezv@udo.mx

(Received Abril 2016; accepted Octubre 2016)

Key words: plasma, fat tissue, toxicokinetic, biological matrices

\begin{abstract}
The organochlorine pesticides, being lipophilic compounds, show extremely high thermodynamic stability and resistance to degradation processes in the environment and in living organisms. They accumulate in lipid rich tissues and distribute between transport compartment (blood) and store compartment (adipose tissue). The purpose of this study is to make a comparison between organochlorine pesticide levels in blood serum and adipose tissue and calculate the differences in their concentrations based on routine biomonitoring study. One hundred and twenty six pair samples of adipose tissue and blood serum during autopsies as a case study were taken and analyzed in Los Mochis Sinaloa, México. Among organochlorine pesticides, higher concentrations correspond to b-HCH, pp'DDE and op'DDT in blood serum lipids; and pp'DDT shows higher concentrations in adipose tissue. Using statistical comparisons, we found a significant linear association of lipid serum organochlorine pesticide concentrations with that in adipose tissue. This concludes that serum lipid organochlorine pesticide concentrations represent an important indicator for both human biological matrices.
\end{abstract}

Palabras clave: plasma, tejido graso, toxicocinética, matrices biológicas

\section{RESUMEN}

Los plaguicidas organoclorados son compuestos lipofílicos que presentan estabilidad termodinámica alta y resistencia a los procesos de degradación ambiental y en los 
organismos vivos. Se acumulan en tejidos ricos en lípidos y se distribuyen entre el compartimento de transporte (sangre) y el compartimento de almacenamiento (tejido adiposo). El objetivo de este estudio fue comparar los niveles de plaguicidas organoclorados en suero sanguíneo y tejido adiposo, así como calcular sus diferencias en concentraciones en ambas matrices biológicas, tomando como base un estudio rutinario de biomonitoreo. Ciento veintiséis pares de muestras de suero sanguíneo y tejido adiposo fueron tomadas durante autopsias y analizadas como estudios de caso en Los Mochis, Sinaloa México. Entre las concentraciones más altas de plaguicidas organoclorados en lípidos de suero sanguíneo, se encuentra el b-HCH, pp'DDE y op'DDT, mientras que en el tejido adiposo el insecticida organoclorado pp'DDT reveló mayor concentración. Aplicando comparaciones estadísticas, se calculó una asociación lineal significativa entre las concentraciones de plaguicidas organoclorados en lípidos del suero sanguíneo comparandas con las del tejido adiposo. Esto permite concluir que las concentraciones de plaguicidas organoclorados en los lípidos del suero sanguíneo, representan un importante indicador para ambas matrices biológicas humanas.

\section{INTRODUCTION}

Biomonitoring concerns the measurement of chemicals or their metabolites in human tissues, specimens or blood (Clewell et al. 2008). The data provided offers direct evidence of human exposure to environmental chemicals and their interpretation in terms of toxicology and human health. The results of biomonitoring studies establish a baseline of information to identify trends in levels and characterize different sources or routes of total exposure. Additionally, biomonitoring data are able to provide information about the extent of exposure at the moment the sample was collected and at the exposure period over a prolonged time (Waliszewski et al. 2014). The biomonitoring data provide a measure of the biologically effective compounds (biomarkers) at the target tissue, where they are presented at a higher concentration. The selection of biomarkers is based on their physical and chemical characteristics, sample accessibility, and availability of analytical methods.

The organochlorine pesticides such as DDT and $\mathrm{HCH}$ show extremely high thermodynamic stability with half-life on the order of years, and reveal resistance to degradation processes, becoming widespread in their geographic distribution (Waliszewski et al. 2012, 2014). These pesticides biomagnify in food chains and bioaccumulate in adipose or lipid-rich tissues of organisms including humans (Caba et al. 2015). Therefore, humans continue to be exposed to different organochlorine pesticides, at background levels and via direct routes of intake (ingestion, inhalation, intrauterine transmission, etc.) (WHO 2003, Alegria et al. 2008, Grandjean et al. 2008, Knobeloch et al. 2009, Lignell et al. 2009, Herrero et al. 2011, Matsumoto et al. 2014,). Environmental exposure to organochlorine pesticides is caused by permanent volatilization and consumption of polluted food, which tends to have small daily variations; these concentrations are indicators of a chronic exposure. In response, these persistent compounds tend to be slowly metabolized and excreted, indicating that its concentrations are stable in blood lipids or adipose tissue (Waliszewski et al. 2012, 2014). Furthermore, the general population now is exposed to low concentrations that are characteristic of environmental exposure and whose toxicokinetic behavior is proper to a single-compartment, first-order clearance model.

A wide array of studies has been conducted on the health effects of organochlorine pesticides, but little attention has been given to their distribution in the human body. The quantification of individual levels within inhabitants exposed to the contaminants over an extended life span was measured by sequential determinations of these pesticides (Herrero et al. 2011, Waliszewski et al. 2012, 2014, Caba et al. 2015, Gallo et al. 2015). Therefore, the organochlorine pesticide residues draw attention to many problems related to human pollution, originated by life in a polluted environment. This is regarded as a critical role to define the ratio of concentration of these pesticides among organism tissues expressed per unit of concentration among different lipid rich compartments (Pramanik and Roy 2014).

However, the toxicokinetic parameter for the model in humans is difficult to describe when there is no data on exposure sources available. In the case of persistent organochlorine pesticides, another complication is estimated on their distribution partitioning pattern into compartments for storage of lipids (Caba et al. 2015). The bioconcentration of organochlorine pesticides in different tissues is 
often conducted to indicate their potential impact on exposed organisms. Thus, the determination of these persistent compounds detected in one body compartment normally is evaluated as exposure biomarker for toxicological studies.

A few reports are available, establishing the extent of high lipophilic compounds, such as organochlorine pesticides: DDT and $\mathrm{HCH}$ residue levels in areas where they were applied only for malaria or ectoparasites control. In addition, there are very few studies involving sanitary actions as the main source of human exposure. Therefore, the purpose of this study is to make a comparison between organochlorine pesticide levels in blood serum and adipose tissue, to establish the environmental exposure to organochlorine pesticides, and also, to calculate the differences in their concentrations between compartments of lipid-rich body tissue, based on routine biomonitoring in Los Mochis, Sinaloa, Mexico.

\section{MATERIAL AND METHODS}

\section{Sampling}

One hundred twenty-six pair samples of adipose tissue and blood serum were taken during autopsies as a case study in the Los Mochis Sinaloa, México. The donors died from natural or accidental causes, and the families of all the participants were asked for consent prior to participate in the study, and samples of adipose tissue and blood were taken from donors for monitoring. The study protocol was reviewed and approved by the Ethics Committee of Universidad de Occidente for human studies. Blood samples were centrifuged to separate blood serum from the cellular part of the blood, and both the blood serum and adipose tissue samples were stored in glass jars, immediately frozen and kept at $-25^{\circ} \mathrm{C}$ until analyzed.

\section{Analytical technique Blood serum}

Chemical analyses of organochlorine pesticides were performed according to a previously detailed method (Waliszewski and Szymczynski 1991, Waliszewski et al. 2004, 2012) with the same modifications. Blood serum samples were placed in a $25 \mathrm{~mL}$ tube with a stopper, weighed to determine sample weight, and acetic acid was added in a ratio of 1:1. Samples were left for $30 \mathrm{~min}$ to hydrolyze and release the pesticides from the endogenous substances of blood. Later, organochlorine pesticide residues were extracted three times with $10 \mathrm{~mL}$ portions of a mixture of hexane and acetone $(9: 1)$.
The extracts were collected in a $100 \mathrm{~mL}$ separatory funnel and washed twice with $25 \mathrm{~mL}$ of distilled water, to remove traces of acetic acid, acetone, and water-soluble substances. The organic phase was collected in a $30 \mathrm{~mL}$ tube with a stopper, and $2 \mathrm{~mL}$ of concentrated sulfuric acid were added. The contents were vigorously shaken for about $1 \mathrm{~min}$ and left for 3 min to ensure good phase separation. The hexane phase was passed through a sodium sulfate layer to a $50 \mathrm{~mL}$ round-bottom flask. The sodium sulfate was rinsed several times with hexane. The extract with the rinses was rotary evaporated to a few drops. The concentrate was quantitatively transferred with hexane to a $1 \mathrm{~mL}$ calibrated tube, and the final volume was adjusted to $1.0 \mathrm{~mL}$ for qualitative and quantitative gas chromatography determinations.

All blood serum samples were analyzed for hexachlorobenzene (HCB); $\alpha-, \beta-, \gamma-\mathrm{HCH}$ (hexachlorocyclohexane); pp'DDE; pp'DDT; and op'DDT. The minimum detection limits for organochlorine pesticide residual were $0.05 \mathrm{mg} / \mathrm{kg}$ on a lipid basis. To determine method quality, a recovery study was performed on ten spiked replicates of blank cow blood sample, which showed pollution levels below the detection limits. The fortification study, performed at $0.5 \mathrm{mg} / \mathrm{kg}$ on a lipid basis, showed mean recovery values from 87 to $96 \%$. The standard deviation and coefficient of variation were below 10 , indicating an excellent repeatability of the method. Concentrated sulfuric acid used in the cleanup step degrades the ubiquitous phthalate esters, interfering in the gas chromatography - electron capture detector (GCECD) identification of organochlorine pesticides, allowing their accurate determination (Waliszewski and Szymczynski 1991).

Total serum lipids were determined colorimetrically with phosphovanillin according to the method recommended by Hycel de Mexico, by using a commercial kit utilized by clinical laboratories (Spinreact 2011). Reference values of the method for Mexican populations are 4.0-8.5 g/L (Spnreact 2011).

\section{Adipose tissue}

The organochlorine pesticide residue determinations in adipose tissues were performed according to a previously described method (Waliszewski and Szymczynski 1982, Waliszewski et al. 2010) with the same modifications. About 2-5 g of adipose tissue were ground with sufficient anhydrous sodium sulfate to obtain a thick powder. The sample was then transferred into a chromatographic column of $1 \mathrm{~cm}$ id and $50 \mathrm{~cm}$ of length fitted with the fritted glass disc, and the content was compacted. The 
lipids containing the organochlorine pesticides were extracted with $150 \mathrm{~mL}$ of hexane. The extract was concentrated in a rotary evaporator to approximately $30 \mathrm{~mL}$. The lipid content in the $10 \mathrm{~mL}$ of concentrated extract was determined gravimetrically. Then, ten milliliters of extract, containing no more than $500 \mathrm{mg}$ of lipids (Waliszewski et al. 2008) were transferred into a $15 \mathrm{~mL}$ tube with a glass stopper. One $\mathrm{mL}$ of concentrated sulfuric acid was added and the tube was tightly closed. The contents were shaken vigorously for about 30 seconds. The tube was left for about 3 min to obtain a good phase separation. The supernatant was dried by passing it through a 3 to $5 \mathrm{~g}$ layer of sodium sulfate, which was then washed with hexane. The combined extract and rinses were rotary evaporated to a small volume (2-3 drops) and quantitatively transferred to a $1 \mathrm{~mL}$ volumetric tube, adjusting the final volume to 1.0 $\mathrm{mL}$ with hexane. Finally, $1 \mu \mathrm{L}$ was injected in the gas chromatograph for qualitative and quantitative determinations.

All of the human adipose tissue samples were analyzed for HCB, a-, b-, g-HCH, pp'DDT, op'DDT, and pp'DDE. The minimum detection limits for the residues oscillate from 0.001 to $0.003 \mathrm{mg} / \mathrm{kg}$ depending on the pesticide. In order to determine the quality of the method, a recovery study was performed on 10 spiked replicates of a blank cow sample of adipose tissue lipids, which showed contamination levels below the detection limits. The fortification study, conducted at $0.01-0.03 \mathrm{mg} / \mathrm{kg}$ levels, depending on the pesticide, showed mean values of recovery between $88 \%$ and $95 \%$.

Gas chromatography analysis was performed with a Varian model 3400CX (Palo Alto, CA, USA) equipped with a ${ }^{63} \mathrm{Ni}$ electron-capture detector (ECD). The operating conditions were as follows: the capillary chromatography column from J\&W Scientific (Folsom, CA, USA) was a DB-608 with a $30 \mathrm{~m}, 0.32 \mathrm{~mm}$ inner diameter (i.d.), and $0.83 \mu \mathrm{m}$ film thickness; the temperature program was $193^{\circ} \mathrm{C}$ (7 min) to $250{ }^{\circ} \mathrm{C}$ at $6{ }^{\circ} \mathrm{C} / \mathrm{min}$, held for $20 \mathrm{~min}$; the carrier gas was nitrogen at $6.3 \mathrm{~mL}$ min and a $1 \mu \mathrm{L}$ aliquot was injected in a splitless mode.

\section{Statistical}

Concentrations of pesticides in each sample were reported as mean (X), standard deviation (SD) and median because the data were not normally distributed according to the Kolmogorov-Smirnov test. Differences in pesticide concentrations were calculated by means of a Kruskal-Wallis test with a confidence level of $95 \%$. In this study, we applied a normal regression model to account for ongoing exposure; which offers a conceptual match to the problem of estimating intrinsic copartition rates, by using serum and adipose tissue concentrations thought to follow an exponential decay by treating organochlorine pesticide concentrations with non-positive difference in log-transformed concentrations between blood and adipose tissue follow-up individuals as censored observations. In order to determine the differences between pesticide concentrations, a Pearson correlation analysis ( $r$ value) and a scatterplot, showing pesticide levels with respect to the compartment studied, were performed. All calculations were conducted by applying Minitab 12 statistical software.

\section{RESULTS AND DISCUSSION}

Concentrations of organochlorine pesticides are in a state of equilibrium between blood serum and adipose tissue or other lipid-rich tissues (Phillips et al. 1989, Porta et al. 2009b). This assumption following Philips et al. (1989) and Porta et al. (2009b) was held for monitored populations, considering they revealed not significant changes in lipid concentrations during the monitoring study. The obtained results of our monitored samples are presented in table $\mathbf{I}$.

Among the organochlorine pesticides determined in the study, higher concentrations correspond to b-HCH, pp'DDE and op'DDT in blood serum lipids. Only pp'DDT manifested higher concentrations in adipose tissue lipids when compared to blood serum lipids. The boxplot of differences between samples

TABLE I. MEAN (X), STANDARD DEVIATION (SD), MEDIAN AND ESTIMATED DIFFERENCES. $95 \%$ CONFIDENCE INTERVALS (CI) FOR DIFFERENCES AMONG ORGANOCHLORINE PESTICIDE CONCENTRATIONS (mg/kg ON LIPID BASIS) IN HUMAN ADIPOSE TISSUE AND BLOOD SERUM SAMPLES.

\begin{tabular}{lccc}
\hline Pesticide & $\mathrm{X} \pm \mathrm{SD}$ & Median & $\begin{array}{c}\text { Difference } \\
\text { and } 95 \% \mathrm{CI}\end{array}$ \\
\hline b-HCH adipose & $0.216 \pm 0.201$ & 0.144 & -0.288 \\
b-HCH blood & $0.503 \pm 0.528$ & 0.392 & $-0.387,-0.188$ \\
pp'DDE adipose & $1.063 \pm 0.543$ & 0.918 & -1.726 \\
pp'DDE blood & $2.789 \pm 1.714$ & 2.399 & $-2.042,-1.409$ \\
op'DDT adipose & $0.062 \pm 0.078$ & 0.040 & -0.068 \\
op'DDT blood & $0.130 \pm 0.164$ & 0.079 & $-0.100,-0.036$ \\
pp'DDT adipose & $0.585 \pm 0.574$ & 0.413 & 0.245 \\
pp'DDT blood & $0.340 \pm 0.396$ & 0.195 & $0.123,0.368$ \\
S-DDT adipose & $1.706 \pm 1.034$ & 1.486 & -1.552 \\
S-DDT blood & $3.258 \pm 1.997$ & 2.909 & $-1.947,-1.157$ \\
\hline
\end{tabular}


are exhibited in figure 1. On the other hand, when applying a Pearson test to determine the correlation between organochlorine pesticide concentrations in binomial samples (adipose tissue and blood serum), the following results were obtained: $b-\mathrm{HCH}$-adipose tissue and $b-\mathrm{HCH}-\mathrm{blood}$ serum $\mathrm{r}=0.721, \mathrm{p}=0.000$; pp'DDE-adipose tissue and pp'DDE-blood serum $r=$ $0.552, \mathrm{p}=0.000$; op'DDT-adipose tissue and op'DDTblood serum $\mathrm{r}=0.747, \mathrm{p}=0.000$; pp'DDT-adipose
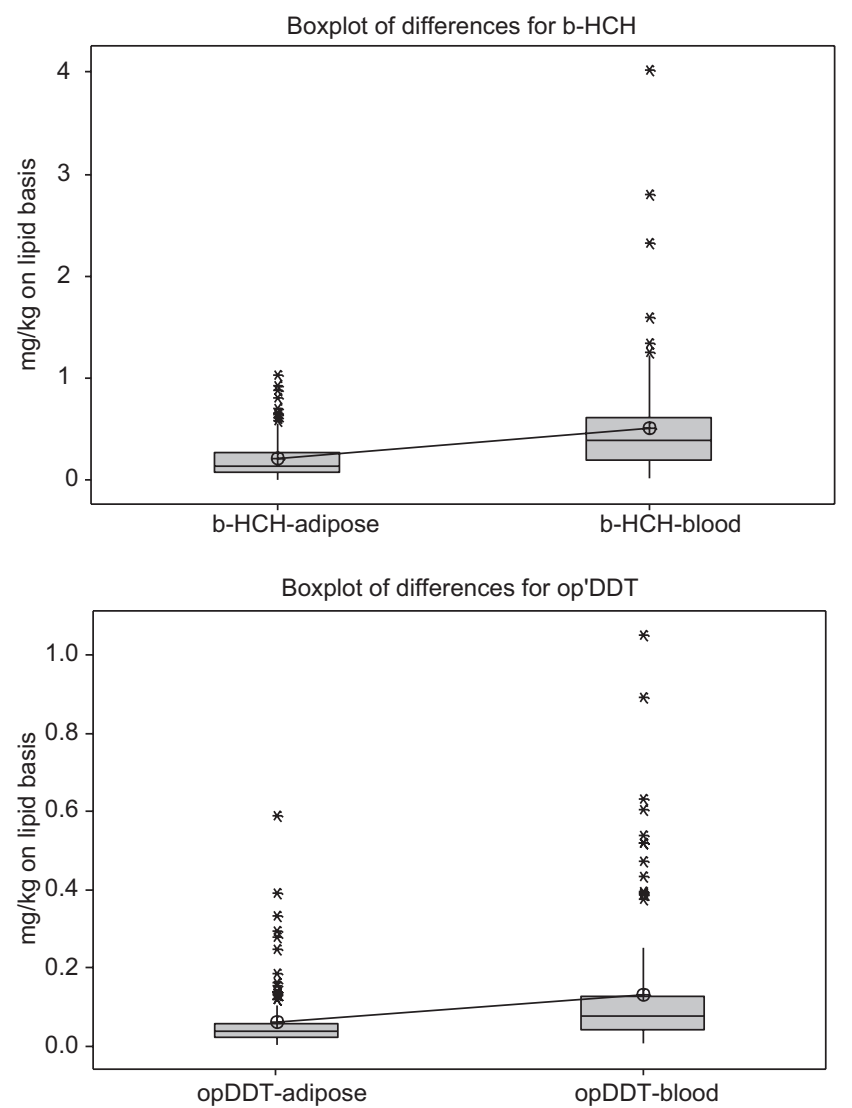

Boxplot of differences for S-DDT

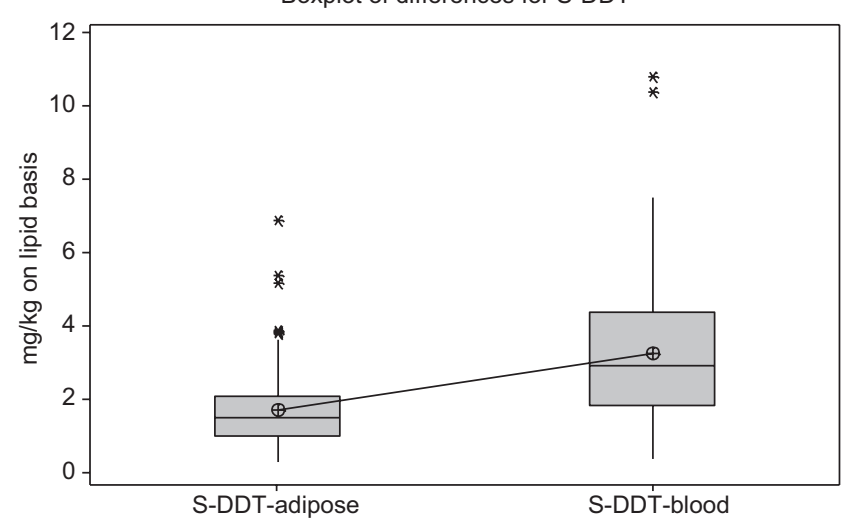

tissue and pp'DDT-blood serum $r=0.686, p=0.000$; S-DDT-adipose tissue and S-DDT-blood serum $\mathrm{r}=$ $0.622, p=0.000$. Higher values of the Pearson correlation factor suggest that organochlorine pesticide concentrations in adipose tissue are positively correlated to that in blood serum. The calculations reveal that estimated values of organochlorine pesticides in blood serum compartment are inversely proportional to adipose tissue concentrations. This is because the
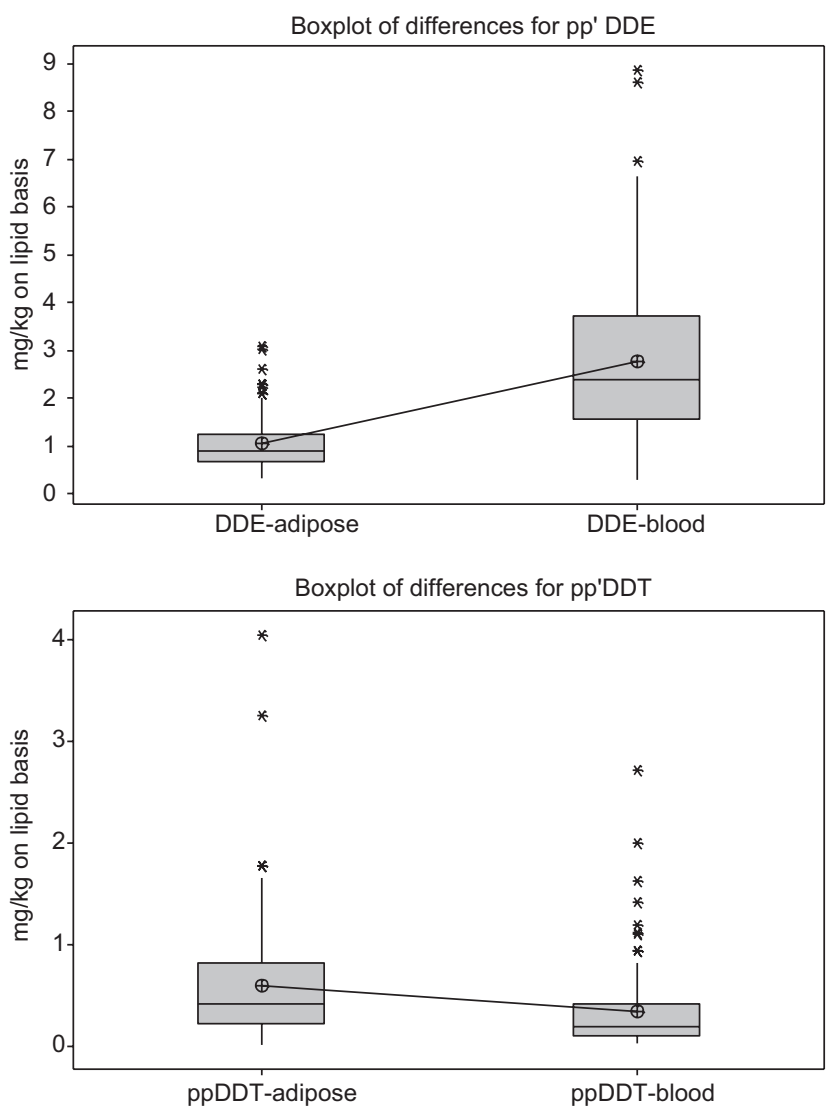

Fig. 1. Boxplot of differences for organochlorine pesticide concentrations ( $\mathrm{mg} / \mathrm{kg}$ on lipid basis) between adipose tissue and blood serum 
tissue elimination function slowly saturate the organism with these pesticides within a monitored range of concentrations. A high level of correlation between concentrations for individual organochlorine pesticides and these two matrices would indicate a degree of interchangeability of lipids among tissues and their copartition between both body compartments.

Su et al. (2014) proposed that there are no differences between lipophilic chemical concentrations, such as organochlorine pesticides, and the apparent distinctions in their concentrations between body compartments as observed in our study, raised through their unequal distribution between target and non-target lipids. The target site concentration is an ideal indicator that reflects the intrinsic accumulation of organochlorine pesticides when their thermodynamic activity reaches a threshold during normal physiological processes. Therefore, pesticides in body compartments achieve a critical concentration within a biophase of the organism, generating critical body residues concentrations (Su et al. 2014). Despite of the above, there are many unresolved questions related to the toxicokinetics of organochlorine pesticides in the human body. Therefore, correcting the blood concentration of these pesticides by total serum lipids is a practice frequently used by many researches, on the premise that lipophilic substances are in a state of equilibrium across body compartments (blood, fat, organs) (Porta et al. 2009a) (Table I). For that reason, the expression of organochlorine pesticide blood levels on total blood lipid concentration improved precision. The equilibrium may not hold permanent lipid concentrations, but is influenced by many factors such as lipid synthesis, and clinical, metabolic and toxicological conditions which may influence the accumulation of organochlorine pesticides and other lipophilic compounds in lipid rich tissues, in their mobilization, in the blood/lipid ratio, and in the blood/organ tissue ratio (López et al. 2014, Caba et al. 2015).

Lipid correction or adjustment of organochlorine pesticides concentrations is option to deal with the lack of information on fasting status of participants, in other words, it expresses the organochlorine pesticide levels by total lipid concentrations when the bias that may cause ignorance of fasting status is potentially much higher than the bias that could cause the influence of these pesticide levels expressed on lipid basis (López et al. 2014, Caba et al. 2015). As a result, we chose the quadratic type of regression model to model the curvature in the relationship between a response variable $(\mathrm{Y})$ and a predictor variable $(\mathrm{X})$, by extending the simple linear regression model (Fig. 2 and Table II). The polynomial regression analysis calculates the $p=0.000$ which suggests that the adipose tissue is a significant predictor of blood serum in organochlorine pesticide concentrations, and the higher coefficient of regression value tells us about the amount of variability in the response that this model accounts for. The quadratic model applied $(\mathrm{p}=0.000)$ appears to provide a good fit to the data, and the coefficient of regression shows that the adipose tissue concentrations indicate the variation in $\log 10$ of blood serum in organochlorine pesticide contents. A visual inspection of the plot presented in figure $\mathbf{2}$ shows that data are evenly spread along the regression line, implying there is no systemic lack of fit.

TABLE II. RESULTS OF POLYNOMIAL REGRESSION ANALYSES FOR ORGANOCHLORINE PESTICIDE CONCENTRATION BETWEEN ADIPOSE TISSUE LIPIDS AND BLOOD SERUM LIPIDS

\begin{tabular}{lcc}
\hline Pesticide & $\mathrm{p}$ & Coefficient of regression \\
\hline b-HCH & 0.000 & $60.7 \%$ \\
pp'DDE & 0.000 & $37.2 \%$ \\
op'DDT & 0.000 & $60.9 \%$ \\
pp'DDT & 0.000 & $59.0 \%$ \\
S-DDT & 0.000 & $43.5 \%$ \\
\hline
\end{tabular}

$\mathrm{p}=$ probability

In order to display the relationship between blood lipids and adipose tissue lipids in organochlorine pesticide concentrations, analysis of covariance was measured. The results obtained are presented in table III, indicating high concentrations of organochlorine pesticides in blood lipids, and a linear association between concentrations determined in serum and adipose tissue lipids, expressed by coefficient of regression and lower $p$ values $(\mathrm{p}<0.01)$.

The results of our study suggest the existence of differences between organochlorine pesticide concentrations measured in serum and adipose tissue lipids, caused by the lipophilic nature of these pesticides and the quantities of lipids presented in each compartment, indicating the usefulness of blood serum lipids to quantify adipose tissue levels. When measurable concentrations caused by lineal relation are detected, serum may predict adipose tissue concentrations for some organochlorine pesticides. Thus, blood serum lipids may be the medium for studies focused on human monitoring, which measure the extent at which serum concentrations may be a proxy for adipose tissue concentrations. While serum lipids 

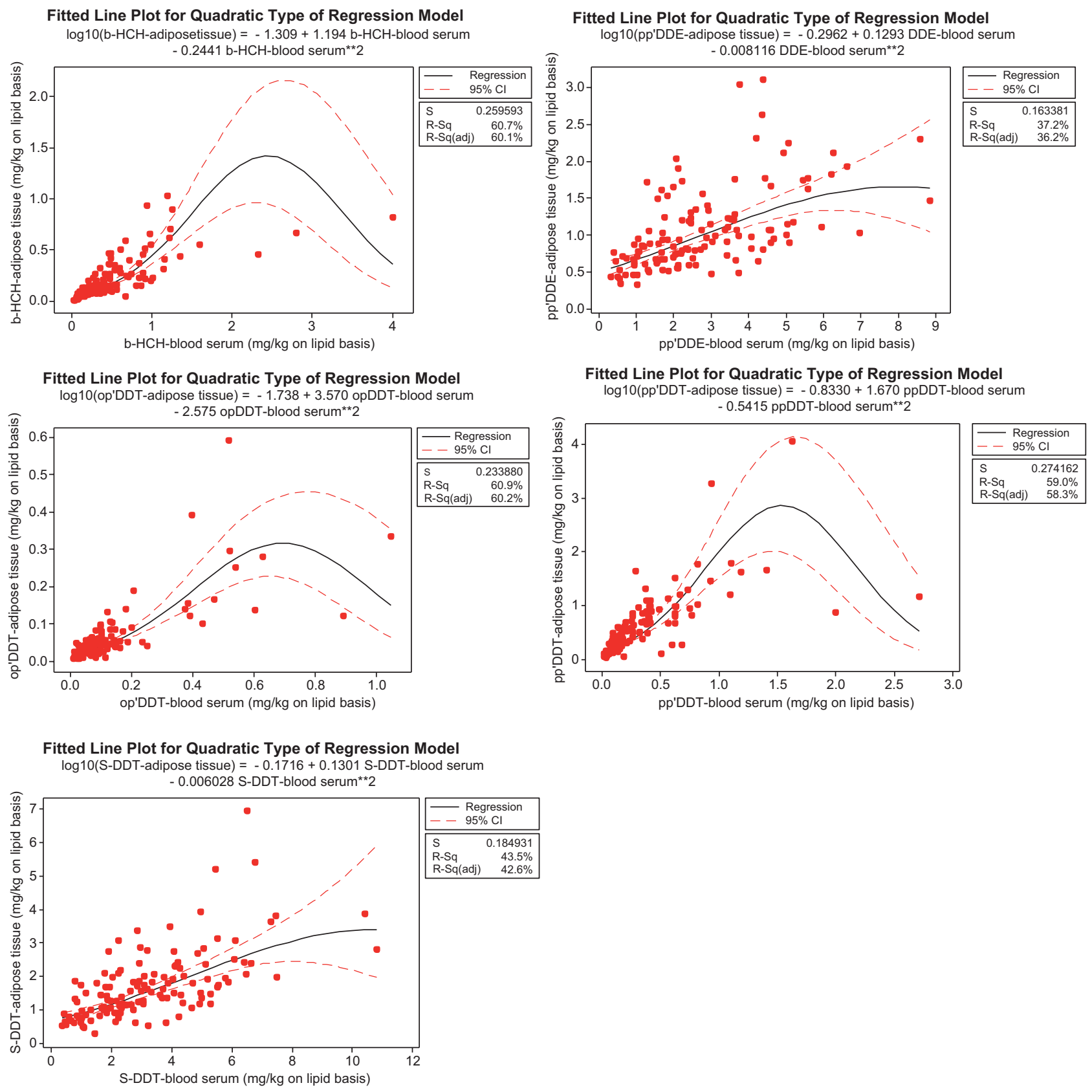

Fig. 2. Boxplot of quadratic type of regression model for modeling curvature in the relationship between a response variable (Y-adipose tissue) and a predictor variable (X-blood serum) by the simple linear regression model of differences for organochlorine pesticide concentrations $(\mathrm{mg} / \mathrm{kg}$ on lipid basis) between adipose tissue and blood serum lipids

are a good proximate for a number of lipophilic compounds, they may have important implications for biomonitoring studies of inhabitants whose exposure profile is expected, and serum concentrations may be useful for their detection. Our findings underlie the assumption that the relation between organochlorine pesticide concentrations is linear. Using all comparisons, we found that the relative abundance of serum organochlorine pesticide concentrations strongly correlates with that in the adipose tissue and there is a significant linear association for both human body compartments.

\section{CONCLUSIONS}

During the monitoring study, organochlorine pesticide residues in inhabitants environmentally 
TABLE III. COVARIANCE ANALYSIS RESULTS OF ORGANOCHLORINE PESTICIDE CONCENTRATIONS (mg/kg ON LIPID BASIS) BETWEEN ADIPOSE TISSUE LIPIDS AND BLOOD SERUM LIPIDS

\begin{tabular}{lcc}
\hline & Adipose & Blood \\
\hline b-HCH adipose & 0.0404 & \\
b-HCH blood & 0.0766 & 0.2795 \\
pp'DDE adipose & 0.2946 & \\
pp'DDE blood & 0.5138 & 2.9368 \\
op'DDT adipose & 0.0062 & \\
op'DDT blood & 0.0096 & 0.0271 \\
pp'DDT adipose & 0.3293 & \\
pp'DDT blood & 0.1564 & 0.1572 \\
S-DDT adipose & 1.0699 & \\
S-DDT blood & 1.2854 & 3.9884 \\
\hline
\end{tabular}

exposed in Sinaloa, Mexico were detected. The use base of serum lipids in organochlorine pesticide concentrations for exposure quantification may provide results for their extrapolation to adipose tissue concentrations, underlying the assumption of a linear relation between these matrices and the fact that serum lipid organochlorine pesticide concentrations represent an important human indicator to compare both biological matrices.

\section{ACKNOWLEDGMENTS}

We thank Programa para el Mejoramiento del Profesorado (PROMEP) for their financial support to this study.

\section{REFERENCES}

Alegria H., Wong F., Jantunen L.M., Bidleman T.F., Salvador-Figueroa M., Gold-Bouchot G., Ceja-Moreno V., Waliszewski S.M. and Infanzon R. (2008). Organochlorine pesticides and PCBs in air of southern México (2002-2004). Atmos. Environ. 42 (38), 8810-8818. DOI: 10.1016/j.atmosenv.2008.04.053

Caba M., Meza E., Waliszewski S.M. and MartínezValenzuela C. (2015). Inverse correlation among organochlorine pesticide levels to total lipid serum contents: a preliminary study in Veracruz, México. Environ. Monitor Assess. 187, 467-472.

DOI: $10.1007 / \mathrm{s} 10661-015-4694-0$

Clewell H.J., Tan Y.M., Campbell J.L. and Andersen M.E. (2008). Quantitative interpretation of human biomonitoring data. Toxicol. Appl. Pharmacol. 231 (1), 122-133. DOI: 10.1016/j.taap.2008.04.021
Gallo M.V., Deane G.D., De Caprio A.P. and Schell L.M. (2015). Changes in persistent organic pollutant levels from adolescence to young adulthood. Environ. Res. 140, 214-224.

DOI: 10.1016/j.envres.2015.03.009

Grandjean P., Budtz-Jorgensen E., Barr D.B., Needham L.L., Weihe P. and Heinzow B. (2008). Elimination half-lives of polychlorinated biphenyl congeners in children. Environ. Sc. Technol. 42 (18), 6991-6996.

Herrero-Mercado M., Waliszewski S.M., Caba M., Martínez-Valenzuela C., Gómez-Arroyo S., Villalobos-Pietrini R., Cantú-Martínez P.C. and Hernández-Chalate F. (2011). Organochlorine pesticide gradient levels among maternal adipose tissue, maternal blood serum and umbilical blood serum. Bull. Environ. Contam. Toxicol. 86 (3), 289-293.

DOI: 10.1007/s00128-011-0204-4

Knobeloch L., Turyk M., Imm P., Schrank C. and Anderson H. (2009). Temporal changes in PCB and DDE levels among a cohort of frequent and infrequent consumers of Great Lakes sportfish. Environ. Res. 109 (1), 66-72. DOI: 10.1016/j.envres.2008.08.010

Lignell S., Aune M., Darnerud P.O., Cnattingius S. and Glynn A. (2009). Persistent organochlorine and organobromine compounds in mother's milk from Swede 1996-2006: compound-specific temporal trends. Environ. Res. 109 (6), 760-767.

DOI: $10.1016 /$ j.envres.2009.04.011

López T., Pumarega J.A., Pollack A.Z., Lee D.H., Richiardi L., Jacobs D.R. Jr., Schisterman E.F. and Porta M. (2014). Adjusting serum concentrations of organochlorine compounds by lipids and symptoms: A causal framework for the association with K-ras mutations in pancreatic cáncer. Chemosphere 114, 219-225.

DOI: 10.1016/j.chemosphere.2014.04.066

Matsumoto S., Akahane M., Kanagawa Y., Koike S., Yoshimura T., Mitoma C., Shibata S., Uchi H., Furue M. and Imamura T. (2009). Variation in half-life of pentachlorodibenzofuran (PeCDF) blood level among Yusho patients. Chemosphere 77 (5), 658-662.

DOI: 10.1016/j.chemosphere.2009.08.009

Phillips D.L., Pirkle J.L., Burse V.W. Bernert J.T. Jr., Henderson L.O. and Needham L.L. (1989). Chlorinated hydrocarbon levels in human serum: effects of fasting and feeding. Arch. Environ. Contam. Toxicol. 18 (4), 495-500.

DOI: $10.1007 / \mathrm{BF} 01055015$

Porta M., Jariod M., López T., Pumarega J., Puigdomènech E., Malats N., Grimalt J.O. and Real F.X. (2009a). Correcting serum concentrations of organochlorine compounds by lipids: alternatives to the organochlorine/total lipids ratio. Environ. Int. 35 (7), 1080-1085. DOI: 10.1016/j.envint.2009.06.004 
Porta M., Pumarega J., López T., Jariod M., Marco E. and Grimalt J.O. (2009b). Influence of tumor stage, symptoms and time of blood draw on serum concentrations of organochlorine compounds in exocrine pancreatic cancer. Cancer Causes Control. 20 (10), 1893-1906. DOI: $10.1007 / \mathrm{s} 10552-009-9383-2$

Pramanik S. and Roy K. (2014). Modeling bioconcentration factor (BCF) using mechanistically interpretable descriptors computed from open source tool "PaDELDescriptor". Environ. Sci. Pollut. Res. 21 (4), 2955 2965. DOI: $10.1007 / \mathrm{s} 11356-013-2247-\mathrm{z}$

Spinreact (2011). Total lipids [Instructions for use]. [online]. http://www.spinreact.com.mx/public/instructivo/ QUIMICA\%20CLINICA/LIQUIDOS/1001270.pdf 20/11/2011.

Su L.M., Liu X., Wang Y., Li J.J., Wang X.H., Sheng L.X. and Zhao Y.H. (2014). The discrimination of excess toxicity from baseline effect: Effect of bioconcentration. Sci. Tot. Environ. 484, 137-145.

DOI: $10.1016 /$ j.scitotenv.2014.03.040

Waliszewski S. M. and Szymczynski G.A. (1982). Simple, low-cost method for determination of selected chlorinated pesticides in fat samples. J. AOAC 65 (3), 677-679.

Waliszewski S.M. and Szymczynski G.A. (1991). Persistent organochlorine pesticides in blood serum and whole blood. Bull. Environ. Contam. Toxicol. 46 (6), 803-809. DOI: 10.1007/BF01689722

Waliszewski S.M., Gómez-Arroyo S., Carvajal O., Villalobos-Pietrini R. and Infanzón R. M. (2004). Uso del ácido sulfúrico en las determinaciones de plaguicidas organoclorados. Rev. Int. Contam. Ambie. 20 (4), 185-192.
Waliszewski S.M., Mojica-García X., Infanzón R.M., Barradas-Dermitz D.M. and Carvajal-Zarrabal O. (2008). Uso del ácido sulfúrico en la determinaciones de plaguicidas organoclorados. I. Calidad químicoanalítica de la precipitación de grasas por el ácido sulfúrico concentrado en muestras con alto contenido de lípidos. Rev. Int. Contam. Ambie. 24 (1), 33-38.

Waliszewski S.M., Valencia-Quintana R., Corona C.A., Herrero M., Sánchez K., Aguirre H., Aldave I.A., Gómez-Arroyo S. and Villalobos-Pietrini R. (2010). Comparison of organochlorine pesticide levels in human adipose tissue of inhabitants from Veracruz and Puebla, Mexico. Arch. Environ. Contam. Toxicol. 58 (1), 230-236. DOI: 10.1007/s00244-009-9325-8

Waliszewski S.M., Caba M., Herrero-Mercado M., Saldariaga-Noreña H., Meza E., Zepeda R., MartínezValenzuela C., Gómez-Arroyo S. and VillalobosPietrini R. (2012). Organochlorine pesticide residue levels in blood serum of in habitants from Veracruz, Mexico. Environ. Monit. Assess. 184 (9), 5613-5621. DOI: $10.1007 / \mathrm{s} 10661-011-2366-2$

Waliszewski S. M., Caba M., Saldarriaga-Noreña H., Martínez A.J., Meza E.,Valencia Quintana R. and Zepeda R. (2014). Organochlorine pesticide level differences among female inhabitants from Veracruz, Puebla and Tabasco, Mexico. Bull. Environ. Contam. Toxicol. 93 (2), 233-237. DOI: 10.1007/s00128-014-1309-3

WHO (2003). Polychlorinated biphenyls: Human health aspects. Concise International Chemical Assessment Document 55. World Health Organization [online]. http://www.who.int/ipcs/publications/cicad/en/cicad55.pdf?ua $=1$ 10/12/2015. 